\title{
Assessment of laboratory scale cylindrical sequencing batch reactor for the treatment of abattoir effluent
}

\author{
Asif Ansari ${ }^{1}$ iD \\ Received: 26 August 2021 / Accepted: 9 November 2021 / Published online: 24 November 2021 \\ (c) Springer Nature Switzerland AG 2021
}

\begin{abstract}
Meat factory effluent contains fat, protein, diluted blood, and suspended solids. As a result, nutrient and organic concentrations in this effluent are incredibly high, and residues are slightly solubilized, likely to impact environmental pollution on streams, rivers, and other watercourses if discharged untreated. The biodegradation of abattoir waste was studied using a laboratory-scale cylindrical sequencing batch reactor (SBR) in aerobic mode. The aerobic sludge was collected from the aeration compartment of a paper and pulp effluent treatment facility and cultivated in a 2.83-L Perspex-based laboratory SBR. The raw wastewater comprised $6494 \pm 2144 \mathrm{mg} / \mathrm{l}$ chemical oxygen demand (COD), $1946 \pm 607 \mathrm{mg} / \mathrm{l} \mathrm{biochemical}$ oxygen demand (BOD), $1722 \pm 159 \mathrm{mg} / \mathrm{l}$ total suspended solids (TSS), $3062 \pm 592 \mathrm{mg} / 1 \mathrm{CaCO}_{3}$ alkalinity, $7.00 \pm 0.27 \mathrm{pH}$. The duration of a complete cycle was $24 \mathrm{~h}$ and comprised four phases: fill (5 min), react (23 h $10 \mathrm{~min})$, settle (40 min) and draw $(5 \mathrm{~min})$. The whole experiment was divided into four phases and the dilution was done with the help of domestic sewage. In the first stage, the reactor was fed four times diluted slaughterhouse effluent on a 24-h cyclic operation for two weeks. After achieving a significant reduction in COD, the organic content of the input was raised by lowering the dilution factor. In the second and third phases, the reactor was fed three times and twice diluted samples for two weeks each operating at the same cyclic interval. In the final stage, raw effluent was fed to the reactor for two more weeks. The average COD value of diluted wastewater in the first, second, third and fourth phase was $1040 \mathrm{mg} / 1,3168 \mathrm{mg} / 1,4800 \mathrm{mg} / \mathrm{l}$, and $5200 \mathrm{mg} / \mathrm{l}$, respectively. The COD removal efficiency at the end of the first, second, third and fourth phase was $83 \%, 93 \%, 85 \%$ and $97 \%$, respectively. The average BOD value of diluted wastewater at the end of the first, second, third and fourth phase was $1120 \mathrm{mg} / \mathrm{l}, 610 \mathrm{mg} / \mathrm{l}, 1502 \mathrm{mg} / \mathrm{l}$, and $1350 \mathrm{mg} / \mathrm{l}$, respectively. The BOD removal efficiency at the end of the first, second, third and fourth phase was $84 \%, 88 \%, 85 \%$ and $98 \%$, respectively. After 8 weeks, at an organic loading rate of $3.06 \mathrm{~kg} / \mathrm{m}^{3} / \mathrm{d}$, the final phase has achieved BOD and COD removal efficiency of $98 \%$ and $97 \%$, respectively. The $\mathrm{pH}$ and alkalinity levels were within acceptable ranges. After two months, the sludge's settling characteristics have improved, and the nitrification efficiency of the reactor was roughly $60 \%$ at the time of deactivation of the reactor.
\end{abstract}

Keywords Abattoir effluent $\cdot$ Alkalinity $\cdot$ Biochemical oxygen demand $\cdot$ Chemical oxygen demand $\cdot \mathrm{pH} \cdot \mathrm{Sequencing}$ batch reactor $\cdot$ Slaughterhouse wastewater $(\mathrm{SWW})$

\section{Introduction}

The slaughter of animals generates an enormous volume of meat, which meets the world's growing protein requirement. Water quality has deteriorated in recent decades as a result of the growing population and industrialization. The meat processing industry consumes $29 \%$ of all freshwater globally

Asif Ansari

asif@gecazamgarh.ac.in

1 Department of Civil Engineering, Rajkiya Engineering College, Azamgarh, Uttar Pradesh, India consumed by the agricultural sector [1, 2]. Furthermore, global beef, swine, and chicken meat production has doubled in the last decade and is expected to grow until 2050 [3]. As a result, the number of slaughterhouses is expanding, leading to a large volume of slaughterhouse wastewater (SWW) must be treated [4]. The global meat production in 2020 reached almost 337.18 million tonnes in the case of bovine, poultry, pig, and ovine as per the meat statistics data of the Food and Agriculture Organization of the United Nations, 2021 [5]. The leading meat-producing countries in 2020 were China, USA, European Union, Brazil, Russia, Mexico, India, and Argentina. Poultry meat production (133.3 million tonnes) 
was most significant compared to other meat productions in that particular year. Table 1 gives the world's meat production and export in the year 2020 [5].

Meat production in India has expanded rapidly in recent years. In 2010, India exported approximately 1.45 million tonnes of beef abroad, generating around 1500 million US dollars in income [6]. In the present scenario, India's meat production and exports have risen to 7.36 million tonnes and 1.23 million tonnes, respectively [5]. Due to Covid19-related market disturbances, inadequate availability of animals for slaughter, and regulatory limits on purchasing and shipping animals, meat exports have decreased marginally. According to India's Central Pollution Control Board (CPCB), the nation has approximately 1176 slaughterhouses and 75 modern abattoirs. The leading meat-producing states are Andhra Pradesh, Uttar Pradesh, Tamil Nadu, and Maharashtra [6].

The properties of slaughterhouse wastewater (SWW) are influenced by several factors, including the size of the slaughtering facility, the type of animals slaughtered, the style of slaughtering involved, the amount of water consumed per animal, and the washing of killing equipment. According to the World Bank Group (2007), for every tonne of cattle carcass, $1.62-9 \mathrm{~m}^{3}$ of water is utilized, and $1.6-8.3 \mathrm{~m}^{3}$ per tonne of pig carcass [7]. In slaughterhouses, large amounts of water are used for evisceration, cleaning, and washing activities [8]. Effluent is generated from all water used in slaughtering and manufacturing units [6]. The discharge of wastewater can make up a significant portion to $80 \%$ of total water usage [9]. Slaughterhouse effluent wastewater is high in pollutants and has the potential to harm the environment. Organic materials, suspended particles, oil and grease, and nutrients are higher in the slaughterhouse sector [2]. Blood, fat, dung, urine, and meat tissues are lost to wastewater streams during abattoir processing
$[10,11]$. One of the principal dissolved contaminants in abattoir wastewater is blood, with the highest COD of any abattoir effluent. The effluent load from a single cow carcass discharged straight into a sewer line would be equivalent to the total sewage discharged by 50 persons on a typical day [12]. Slaughterhouse effluent, along with different industrial effluents, is investigated to gain a better understanding of their characteristics (Table 2).

The United States Environmental Protection Agency (US EPA) has recognized SWWs as one of the most environmentally hazardous industrial wastewaters since improper management is one of the culprits of river deoxygenation and groundwater contamination [19]. The discharge of raw SWW into water bodies impacts water quality, notably, because it reduces dissolved oxygen (DO), which can lead to aquatic life mortality [20]. Furthermore, macronutrients such as nitrogen and phosphorus have the potential to produce eutrophication. The release of these nutrients causes an overabundance of algae growth and, as a result, deterioration. As a result of the mineralization of algae, aquatic life may deteriorate due to a decrease in DO levels [21]. If wastes from slaughterhouses are released without essential treatment, municipal sewers will become clogged or overburdened [8]. As a result, it is critical to use proper treatment to control the discharge of mixed organic carbon and nitrogen-laden wastewater. If effective process control can be ensured, biological treatment has been shown to be a relatively benign and energy efficient method of treating wastewater [11]. In terms of bulk parameters like BOD, COD, and TN, particular emphasis is paid to organic and nutrient removal. Table 3 displays the findings of prior studies on abattoir wastewater treatment by numerous researchers. SWW treatment efficiency varies widely and is dependent on SWW parameters, treatment time, influent concentration, and treatment type.
Table 1 World's meat production and export in 2020

\begin{tabular}{lrrrrrrrrr}
\hline & World & China & USA & EU & Brazil & Russia & Mexico & India & Argentina \\
\hline Meat production & 337.18 & 77.91 & 48.68 & 48.60 & 28.83 & 11.17 & 7.52 & 7.36 & 6.30 \\
Meat export & 38.69 & 0.71 & 8.45 & 6.82 & 7.99 & 0.58 & 0.70 & 1.23 & 1.10 \\
\hline
\end{tabular}

All values in million tonnes

Table 2 Characteristics of different industrial wastewater

\begin{tabular}{lllllllll}
\hline Parameter & $\mathrm{pH}$ & $\mathrm{COD}(\mathrm{mg} / \mathrm{l})$ & $\mathrm{BOD}(\mathrm{mg} / \mathrm{l})$ & $\mathrm{TN}(\mathrm{mg} / \mathrm{l})$ & $\mathrm{TP}(\mathrm{mg} / \mathrm{l})$ & $\mathrm{TSS}(\mathrm{mg} / \mathrm{l})$ & Alkalinity $(\mathrm{mg} / \mathrm{l})$ & References \\
\hline Slaughterhouse wastewater & $5-7.8$ & $1100-15,000$ & $600-3900$ & $50-840$ & $15-200$ & $220-6400$ & $350-1340$ & {$[13]$} \\
Pharmaceutical wastewater & $4.2-4.5$ & $5000-80,000$ & - & $135-1250$ & $30-120$ & $900-18,800$ & - & {$[14]$} \\
Dairy wastewater & $6-11$ & $1150-9200$ & - & - & $8-68$ & $340-1730$ & $320-970$ \\
Livestock wastewater & - & $6190-78,600$ & $3940-34,600$ & $1530-6500$ & $116-1770$ & $1850-29,000$ & - & {$[15]$} \\
Textile wastewater & $7-7.2$ & $773-1290$ & $400-490$ & - & $9.4-27.9$ & - & - & {$[16]$} \\
Oil refinery wastewater & $6.9-10$ & $125-1095$ & - & - & - & $9-93$ & - & {$[17]$} \\
\hline
\end{tabular}


Table 3 Comparison of different slaughterhouse wastewater treatment methods

\begin{tabular}{|c|c|c|c|c|c|c|c|c|}
\hline Reactor & $\begin{array}{l}\text { Influent } \\
\text { COD (mg/l) }\end{array}$ & $\begin{array}{l}\text { COD } \\
\text { Removal } \\
(\%)\end{array}$ & $\begin{array}{l}\text { Influent } \\
\text { BOD (mg/l) }\end{array}$ & $\begin{array}{l}\text { BOD } \\
\text { Removal } \\
(\%)\end{array}$ & $\begin{array}{l}\text { Influent TN } \\
(\mathrm{mg} / \mathrm{l})\end{array}$ & $\begin{array}{l}\mathrm{TN} \\
\text { Removal } \\
(\%)\end{array}$ & HRT (h) & References \\
\hline Electrocoagulation & 2171 & 85 & 1123 & - & 148 & - & 1 & {$[22]$} \\
\hline Sequencing batch reactor & 6580 & 81 & - & - & 3321 & 95 & 96 & [23] \\
\hline Anaerobic filter & 15,800 & 60 & - & - & - & - & 46 & [24] \\
\hline Anaerobic lagoon & 9216 & 59 & 5088 & 73 & 343 & - & 48 & [25] \\
\hline Anaerobic filter-ultrafiltration & 1778 & 95 & - & - & 374 & 78 & 48 & [26] \\
\hline Electrocoagulation & 3337 & 78 & 1950 & - & - & - & 1 & [27] \\
\hline Sequencing batch reactor & 6057 & 98 & 4240 & - & 576 & 98 & 161 & [28] \\
\hline Anaerobic filter & 88 & 80 & - & - & - & 90 & 24 & [29] \\
\hline Anaerobic digester & 18,600 & - & - & - & 5200 & 66 & 2640 & {$[30]$} \\
\hline Microfiltration & 480 & 91 & - & - & 115 & 45 & 48 & [31] \\
\hline Constructed wetland & 468 & 60 & - & - & 61 & 46 & 28 & [32] \\
\hline Sequencing batch reactor & 6057 & 93 & 4240 & - & 576 & 93 & 12 & [33] \\
\hline Advanced oxidation process & 406 & 84 & - & - & - & - & 1 & {$[34]$} \\
\hline Sequencing batch reactor & 8604 & 80 & - & - & 1493 & 88 & 3 & {$[35]$} \\
\hline Sequencing batch reactor & 356 & - & - & - & 175 & 91 & 12 & {$[36]$} \\
\hline UST-AF-UF* & 5200 & 96 & - & - & 74 & - & 343 & [37] \\
\hline Advanced oxidation process & - & - & 340 & - & 55 & - & 2 & {$[38]$} \\
\hline Cylindrical SBR & 4332 & 97 & 1350 & 98 & 23 & 60 & 24 & Present study \\
\hline
\end{tabular}

*Ultrasound technology-anaerobic filter-ultrafiltration

Aerobic wastewater treatment techniques have several advantages, including reduced odor emission, rapid biological growth rate, and quick temperature and loading rate adjustments. On the other hand, aerobic systems have higher operational costs than anaerobic systems due to the maintenance and energy required for artificial oxygenation. Aerobic activated sludge (AS), rotating biological contactors (RBCs), and sequencing batch reactors (SBRs) are examples of aerobic unit operations for SWW treatment [39]. The Sequencing Batch Reactor (SBR) is a more advanced variant of the activated sludge process that treats biological wastewater in a fill-and-draw mode. Fill-react-settle-draw-idle is a cyclic process that SBRs go through [40, 41]. An SBR reactor differs from a traditional activated sludge system. It accomplishes equalization, aeration, and sedimentation in a time sequence rather than the traditional space sequence used in continuous-flow systems. According to USEPA report (1983) "The SBR is nothing more than an activated sludge system that acts in time rather than space" [19].

SBRs are widely regarded as one of the most accessible methods for treating abattoir wastewater [42] due to their ability to extract organic carbon, suspended particles, and nutrients from wastewater in a single tank and their low operating and capital costs [43]. Several process modifications in the duration associated with each stage can be made to remove nitrogen and phosphorus from wastewater [44, 45]. With considerable success, SBRs have been used to treat landfill leachate [46, 47], tannery wastewater [48, 49], phenolic wastewater [50,51], and a range of other industrial wastewaters. The cylindrical Sequencing batch reactor has begun to gain renown as a better biological treatment system [52-54] due to its low space and power needs, ability to break down harmful contaminants, and ability to withstand greater organic loads and shock loads. Despite the benefits of the aforementioned elements affecting SBR system performance, various aspects such as influent characteristics, organic loading rate, carbon source, $\mathrm{pH}$, dissolved oxygen, hydraulic retention time, sludge retention time, feed pattern, cycle length, settleability, and temperature might affect its performance [55]. In simultaneous $\mathrm{N}$ and $\mathrm{P}$ removal systems, low temperature is a significant difficulty [56]. Furthermore, it necessitates expert labor, continuous power, and costly maintenance [57]. The purpose of this study is to evaluate the performance efficacy of a cylindrical Sequencing Batch reactor for the treatment of abattoir effluent.

\section{Materials and methods}

In this experiment, industrial effluent was collected from a nearby slaughterhouse located in the district of Azamgarh, Uttar Pradesh, India. The Sequencing Batch Reactor System (SBR) was made up of Perspex material and had a total volume of $2.83 \mathrm{~L}$. The cylindrical reactor had a diameter 
of $6 \mathrm{~cm}$ and a height of $100 \mathrm{~cm}$. During the aerobic phase of the reaction period, a 5.0-W air pump was used to supply diffused air from the bottom of the reactor. Automatic on-off timers with various time-dependent cycles were used to automate the complete experimental setup. Throughout the investigation, raw effluent samples were collected five times in $20.0 \mathrm{~L}$ plastic containers from the equalization tank of the meat factory and stored in the laboratory refrigerator at $4{ }^{\circ} \mathrm{C}$. The influent of the SBR was placed in a tank with a capacity of $12 \mathrm{~L}$. Figure 1 shows the experimental laboratory setup used in the study. The reactor was cycled for $24 \mathrm{~h}$, with $5 \mathrm{~min}$ of influent filing, $23 \mathrm{~h} 10 \mathrm{~min}$ of aeration, $40 \mathrm{~min}$ of settling, and 5 min of effluent withdrawal.
The reactor was seeded with aerobic sludge obtained from the aeration tank of the paper and pulp wastewater treatment plant and cultivated in the laboratory under ambient conditions. The reactor was left open to allow a diverse population of bacteria to grow. The effluent was collected from a sampling port located at $50 \mathrm{~cm}$ from the bottom of the reactor, with a volumetric exchange ratio of $50 \%$, which was preferable as it would result in a higher volumetric turnover and allow the use of smaller reactors [58]. The sampling port at $30 \mathrm{~cm}$ height from the bottom of the reactor was used for MLSS collection and periodical sludge wasting. The sludge retention time (SRT) was manually managed by withdrawing excess volumes of mixed liquor from the reactor at an

Fig. 1 Cylindrical SBR

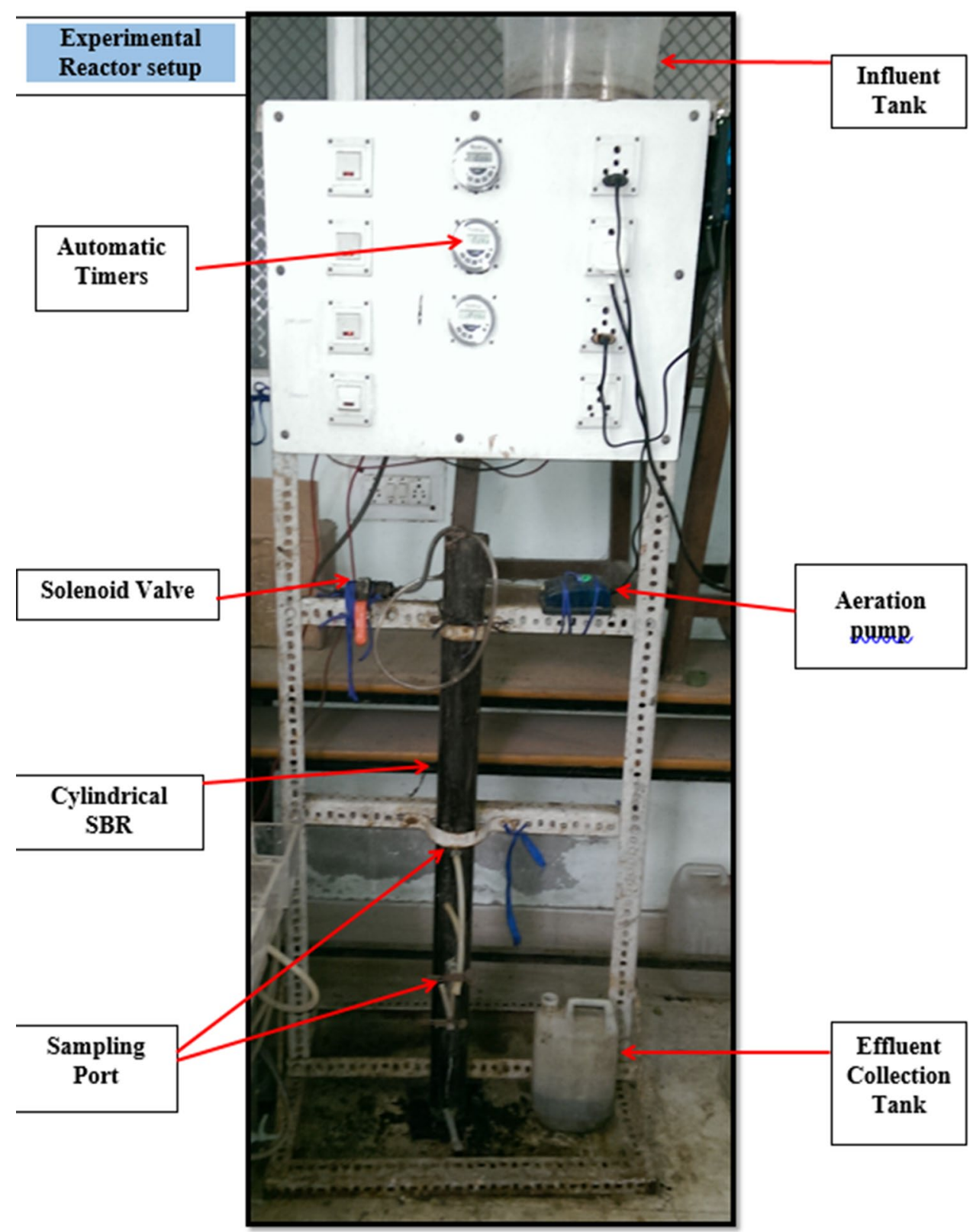


interval of one week. Table 4 shows the characteristics of the raw wastewater collected from the industry.

The overall experiment was divided into four phases, and the dilution was done with the help of domestic sewage. The reactor was fed four times with diluted slaughterhouse effluent on a 24-h cyclic operation for two weeks in the first stage. After achieving a significant reduction in COD, the organic content of the input was raised by lowering the dilution factor. In the second and third phases, the reactor was fed three times and two times diluted samples for two weeks, each operating at the same cyclic interval. In the final stage, raw effluent was provided to the reactor for two more weeks. The reactor was continuously monitored for an overall period of two months. The duration and COD concentration of the influent feed to the reactor is shown in Table 5 .

The procedures given in Standard Methods were employed to carry out the analytical techniques used in this investigation [59]. Chemical oxygen demand (COD) (standard code: 5220$)$, biochemical oxygen demand $\left(\mathrm{BOD}_{5}\right)$ (standard code: 5210B), total suspended solids (TSS) (standard code: 2540), and alkalinity (standard code: 2320 ). The $\mathrm{pH}$ was monitored using a $\mathrm{pH}$ meter (HACK $\mathrm{pH}$ Meter HQ 90D) (standard code: 4500-H), Sludge volume index (SVI) (standard code: 2710D), MLSS concentrations in the samples (standard code: 2540D).

\section{Results and discussion}

This study aimed to assess the efficacy of a laboratory-scale cylindrical sequencing batch reactor for the aerobic treatment of Slaughterhouse wastewater. In order to start the reactor, an active microbial seed was required. The active bacteria will quickly adapt to the industrial wastewater and the cylindrical SBR will start functioning. Therefore, digested waste from the paper and pulp mill was used to seed the reactor and operated at room temperature. Aerobic bacteria degrade the organic matter into $\mathrm{CO}_{2}, \mathrm{H}_{2} \mathrm{O}$ and new cells. The reactor was left open to release $\mathrm{CO}_{2}$, excess $\mathrm{O}_{2}$ and other dissolved gases into the atmosphere. Organic carbon, which is the energy source for heterogenic and denitrifying microorganisms, is known as chemical oxygen demand
Table 5 COD concentration of influent feed to the reactor

\begin{tabular}{llll}
\hline Stage & Dilution factor & $\begin{array}{l}\text { COD influent (in } \\
\text { reactor) } \mathrm{mg} / \mathrm{l}\end{array}$ & Total days \\
\hline Phase 1 & Four times & 1040 & 16 days \\
Phase 2 & Three times & 3168 & 13 days \\
Phase 3 & Two times & 4800 & 18 days \\
Phase 4 & without dilution (raw & 5200 & 16 days \\
& wastewater) & & \\
\hline
\end{tabular}

(COD). Throughout the course of the study, the raw wastewater sample was collected five times from the industry at an interval of two weeks. The properties of the collected samples vary depending on the time and operations taking place in the industry. Wastewater sample was collected from the equalization tank of the Effluent Treatment Plant (ETP) of the abattoir industry.

As demonstrated in Fig. 2, the COD value of raw wastewater at different time intervals varies between $4160 \mathrm{mg} / \mathrm{l}$ and $9408 \mathrm{mg} / \mathrm{l}$ with an average COD value of $6494 \pm 2144$ $(\mathrm{mg} / \mathrm{l})$. Similar values have been reported in different studies [23, 25, 28, 33, 35, 37]. As demonstrated in Fig. 3, the $\mathrm{pH}$ value of raw wastewater at different time intervals varies between 6.98 and 7.70 with an average $\mathrm{pH}$ value of $7.00 \pm 0.27$. Similar values have been reported in different studies [13].

The average COD value of collected raw wastewater was in the range of $6494 \pm 2144(\mathrm{mg} / \mathrm{l})$; therefore it was four times diluted with the help of domestic sewage prior feeding it to the reactor. The reactor was operated on a $24-\mathrm{h}$ cyclic operation. The influent COD was then increased by reducing the dilution factor till optimum COD removal efficiency was achieved. Later on, the raw effluent was fed to the reactor, and the performance of the reactor was monitored in terms of COD removal efficiency.

Figure 4 shows the variation of influent, effluent, and removal efficiency of COD with time. The average value of diluted wastewater in the first, second, third and fourth phase was $1040 \mathrm{mg} / \mathrm{l}, 3168 \mathrm{mg} / \mathrm{l}, 4800 \mathrm{mg} / \mathrm{l}$, and $5200 \mathrm{mg} / \mathrm{l}$, respectively. The COD removal efficiency at the end of the first, second, third and fourth phase was $83 \%, 93 \%, 85 \%$ and
Table 4 Characteristics of the raw wastewater used in the Study

\begin{tabular}{llllll}
\hline Wastewater characteristics & Average & Std deviation & Minimum & Maximum & $\mathrm{N}^{*}=\mathrm{a} \times \mathrm{b}$ \\
\hline $\mathrm{COD}(\mathrm{mg} / \mathrm{L})$ & 6494 & 2144 & 4160 & 9408 & 15 \\
$\mathrm{BOD}(\mathrm{mg} / \mathrm{L})$ & 1946 & 607 & 1300 & 2808 & 15 \\
$\mathrm{TSS}(\mathrm{mg} / \mathrm{L})$ & 1722 & 159 & 2250 & 1962 & 15 \\
Alkalinity as $\mathrm{CaCO}_{3}(\mathrm{mg} / \mathrm{L})$ & 3062 & 592 & 2250 & 3900 & 15 \\
$\mathrm{pH}$ & 7.00 & 0.27 & 6.98 & 7.70 & 15 \\
\hline
\end{tabular}

*Number of samples analyzed; $a=3$ (samples of each parameter); $b=5$ (frequency of industry visit for sample collection) 
Fig. 2 Variation of raw wastewater with time

Fig. 3 Variation of raw wastewater $\mathrm{pH}$ with time

Fig. 4 Performance of SBR during 62 days of operation for influent, effluent, and COD removal efficiency
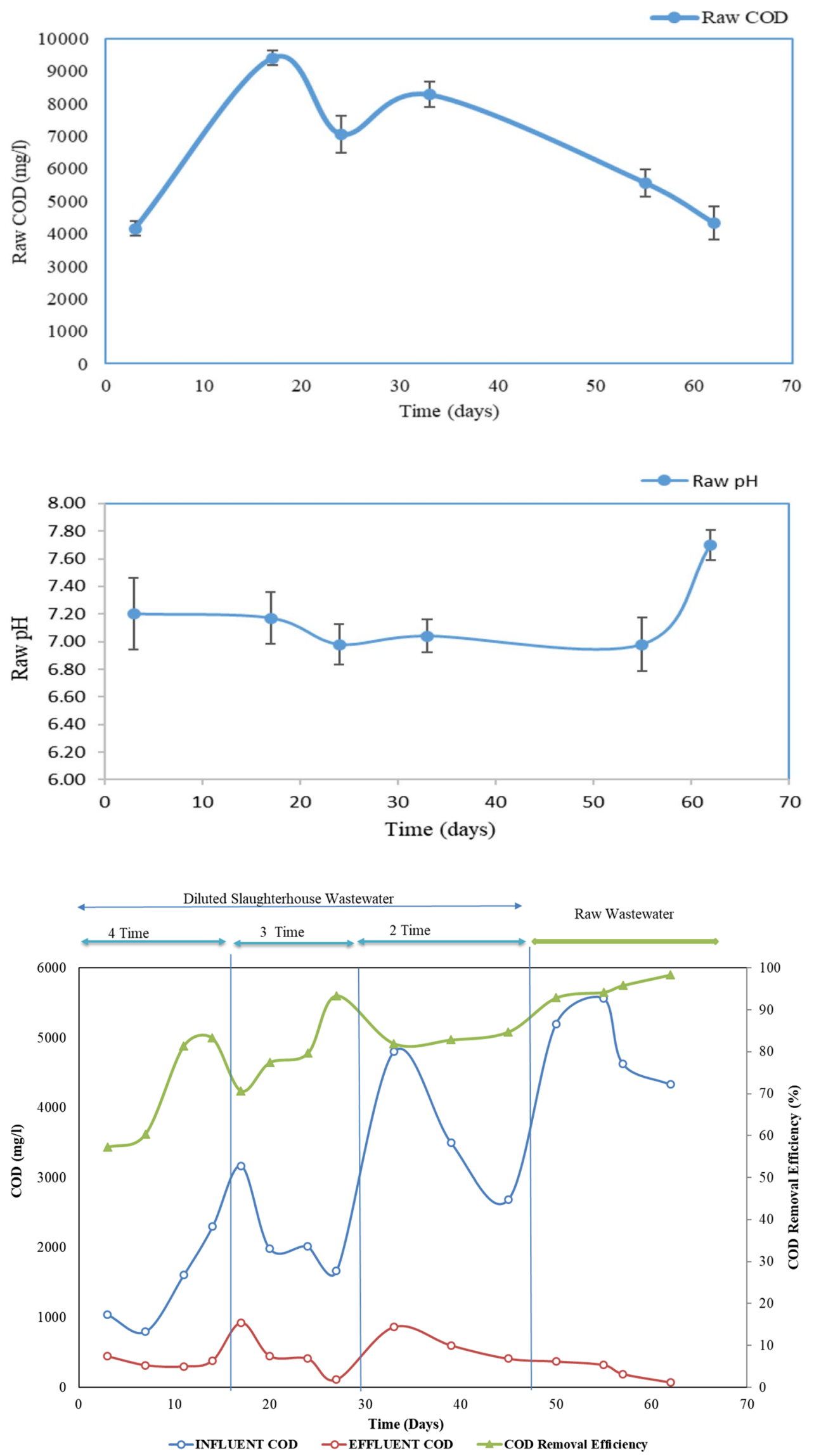
$97 \%$, respectively. It is seen that in each dilution phase, COD removal efficiency is increasing with time, despite variations in the influent COD values. The reactor was operated at a 24-h cyclic operation for 62 days. The variation in influent COD does not affect the COD removal efficiency, which shows that the microorganisms have become acclimatized to the slaughterhouse industry wastewater. At the termination time of the reactor, i.e., on the 62nd day, the COD removal efficiency of the cylindrical SBR was $97 \%$ at an organic loading rate of $3.06 \mathrm{~kg} / \mathrm{m}^{3} / \mathrm{d}$. Similar COD removal efficiency values have been reported in different studies [28, $31,33]$. Therefore, we have decided to terminate the reactor. [59-61].

Similar to the COD graph, Fig. 5 shows the variation of influent, effluent and removal efficiency of BOD with time. The BOD values of raw wastewater at different time intervals vary between $1300 \mathrm{mg} / \mathrm{l}$ and $2808 \mathrm{mg} / \mathrm{l}$, with an average BOD value of $1946 \pm 607(\mathrm{mg} / \mathrm{l})$. The average value of diluted wastewater at the end of the first, second, third and fourth phase was $1120 \mathrm{mg} / \mathrm{l}, 610 \mathrm{mg} / \mathrm{l}, 1502 \mathrm{mg} / \mathrm{l}$, and $1350 \mathrm{mg} / \mathrm{l}$, respectively. The BOD removal efficiency at the end of the first, second, third and fourth phase was $84 \%$, $88 \%, 85 \%$ and $98 \%$, respectively. It is seen that in each dilution phase, BOD removal efficiency is increasing with time, despite variations in the influent BOD values. The variation in influent BOD does not affect the BOD removal efficiency, which shows that the microorganisms have become acclimatized to the slaughterhouse industry wastewater. At the termination time of the reactor, i.e., on the 62 nd day, the BOD removal efficiency of the cylindrical SBR was $98 \%$ at an organic loading rate of $3.06 \mathrm{~kg} / \mathrm{m}^{3} / \mathrm{d}$. Similar BOD removal efficiency values have been reported in different studies [62, 63].

Figure 6 shows a laboratory snapshot of the glass beaker containing a sample of influent feed and treated effluent at the termination time of the reactor. It shows $97 \%$ COD removal and $98 \%$ BOD removal efficiency.

In biological systems, $\mathrm{pH}$ and alkalinity concentrations are essential parameters for bacterial metabolism. The $\mathrm{pH}$ value has an impact on determining the activity of microorganisms. For many microorganisms, the ideal living conditions are at a relatively neutral $\mathrm{pH}$ value. Figure 7 shows the variation of influent and effluent $\mathrm{pH}$ with time. In the present study, the $\mathrm{pH}$ was mostly found to be between 7.0 and 8.0.

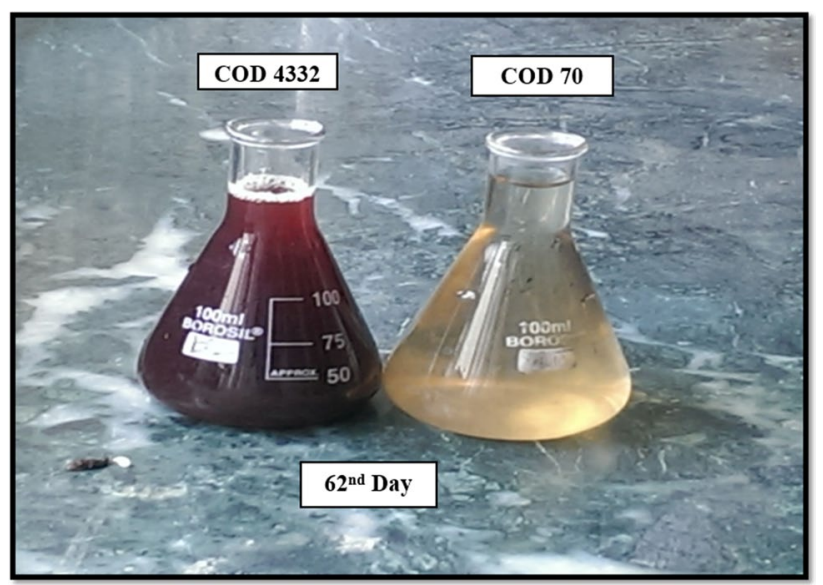

Fig. 6 Influent and effluent of SBR samples (in the laboratory) at the time of the reactor's termination had $97 \%$ COD removal and $98 \%$ BOD removal efficiency

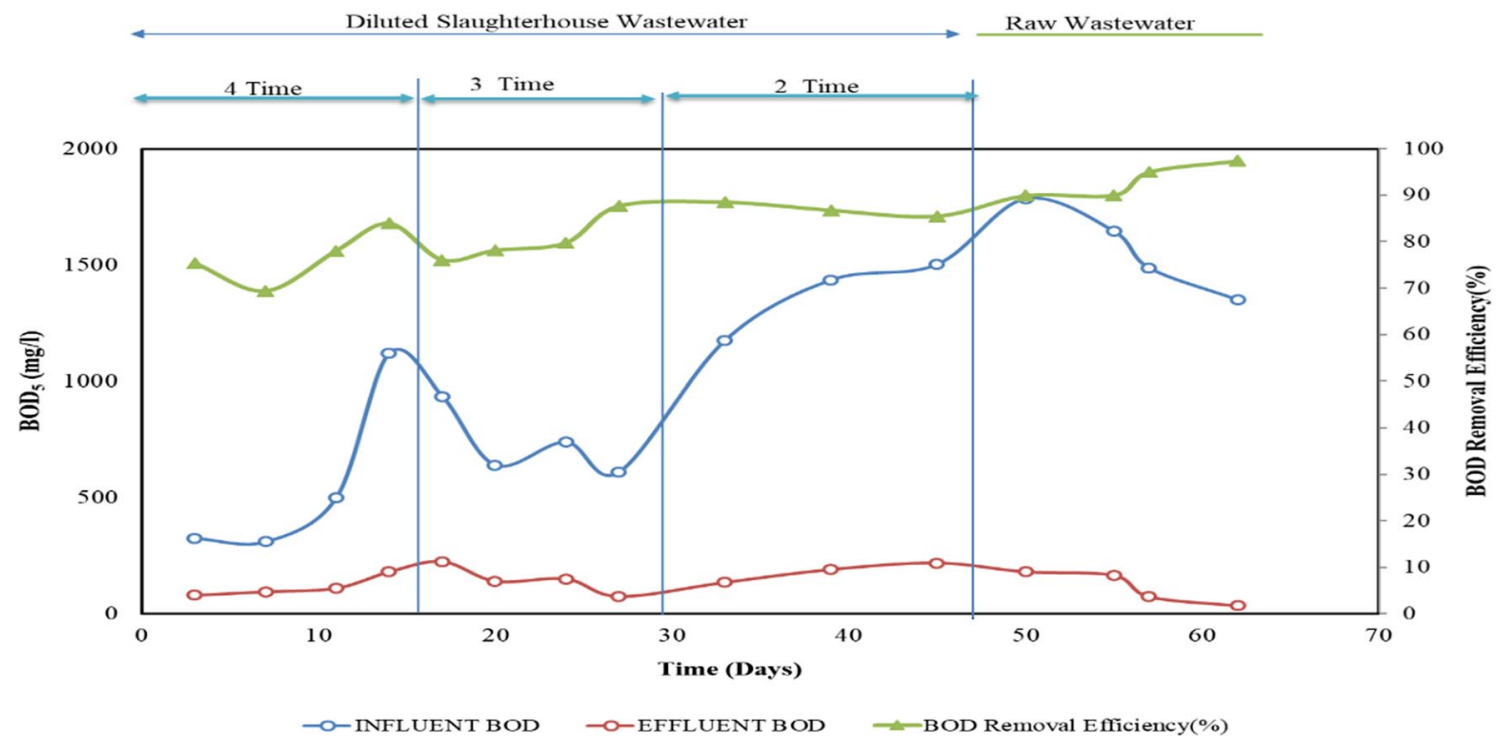

Fig. 5 Performance of SBR during 62 days of operation for influent, effluent, and BOD removal efficiency 
Fig. 7 Variation of $\mathrm{pH}$ with time
घH-Influent $\quad \mathrm{pH}$-Effluent

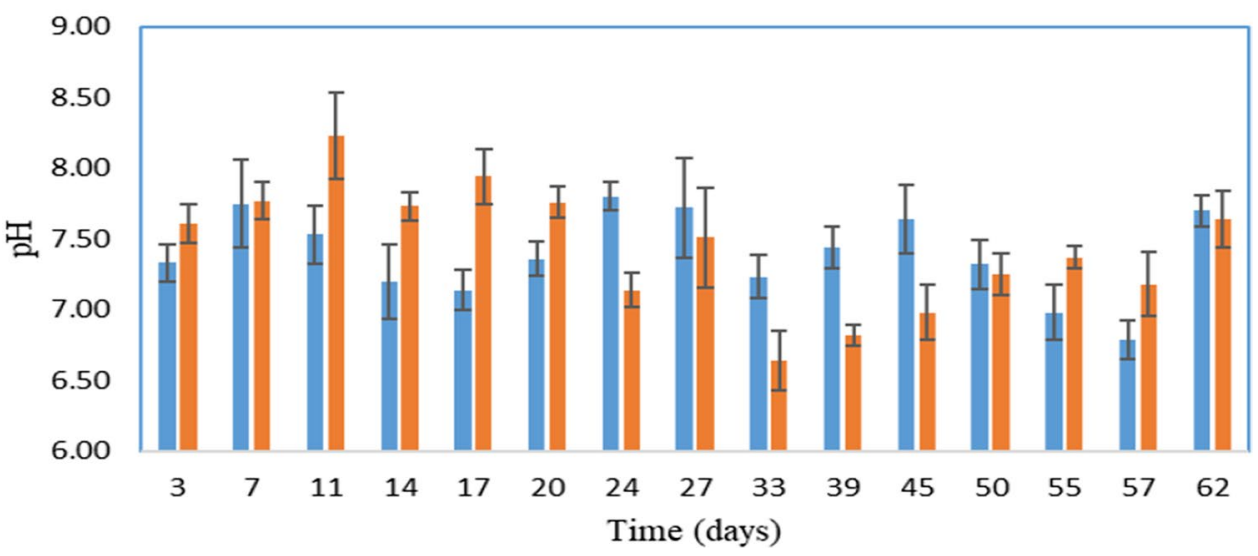

This is beneficial for the proper functioning of the reactor [64]. A similar $\mathrm{pH}$ range has been reported in previous studies [65]. For organic carbon oxidation and nitrification, the $\mathrm{pH}$ value decreases; for ammonification and denitrification, the $\mathrm{pH}$ value increases [11]. Moreover, to avoid damage to the sewage systems and the connected treatment plants, the $\mathrm{pH}$ value of the discharged effluent should be between 5.5 and 9 [6].

The alkalinity of a system is used to determine the stability of the reactor. Because different degrees of nitrification (alkalinity consumption) and denitrification (alkalinity production) contribute to the change of alkalinity in the system, it has a close relationship with SBR operating parameters [11]. The alkalinity content regulates the $\mathrm{pH}$ level in the reactors. Bacterial growth was ensured by high alkalinity and $\mathrm{pH}$ control [66]. The alkalinity value of raw wastewater at different time intervals varies between 2250 and 3900, with an average value of $3062 \pm 592$. Figure 8 shows the variation of influent and effluent alkalinity with time. The effluent alkalinity was above $1000 \mathrm{mg} / \mathrm{L}$ for most of the time.
Since enough alkalinity is required for effective nitrification, this concentration is close to the recommended value of $1,000 \mathrm{mg} / \mathrm{L}$ as $\mathrm{CaCO}_{3}[9,59]$. The treated effluent contained a total alkalinity concentration in the narrow range of 500-600 mg/L as $\mathrm{CaCO}_{3}$ (Fig. 8).

The sludge volume index (SVI) and mixed liquid suspended solids (MLSS) concentration in the reactor were used to track biomass growth. In a muffle furnace, mixed liquor suspended solids (MLSS) and volatile liquor suspended solids (MLVSS) were measured using a gravimetric method at $103-105^{\circ} \mathrm{C}$ and $550{ }^{\circ} \mathrm{C}$, respectively. In the present study, VSS was $6370 \mathrm{mg} / \mathrm{l}$ and $7000 \mathrm{mg} / \mathrm{l}$ on the 56th day and 62nd day, respectively. The increase in VSS in the reactor indicated that the microorganisms were sprouting in a favorable environment [11]. This shows growth in microorganisms. This is beneficial for the efficient functioning of the reactor. Microorganisms convert organic matter into gaseous end products and new cells.

The settling quality of sludge is described by the Sludge Volume Index (SVI). It determines the sludge
Fig. 8 Variation of Alkalinity with Time alkalinity -Influent (mg/1) E Alkalinity -Effluent (mg/1)

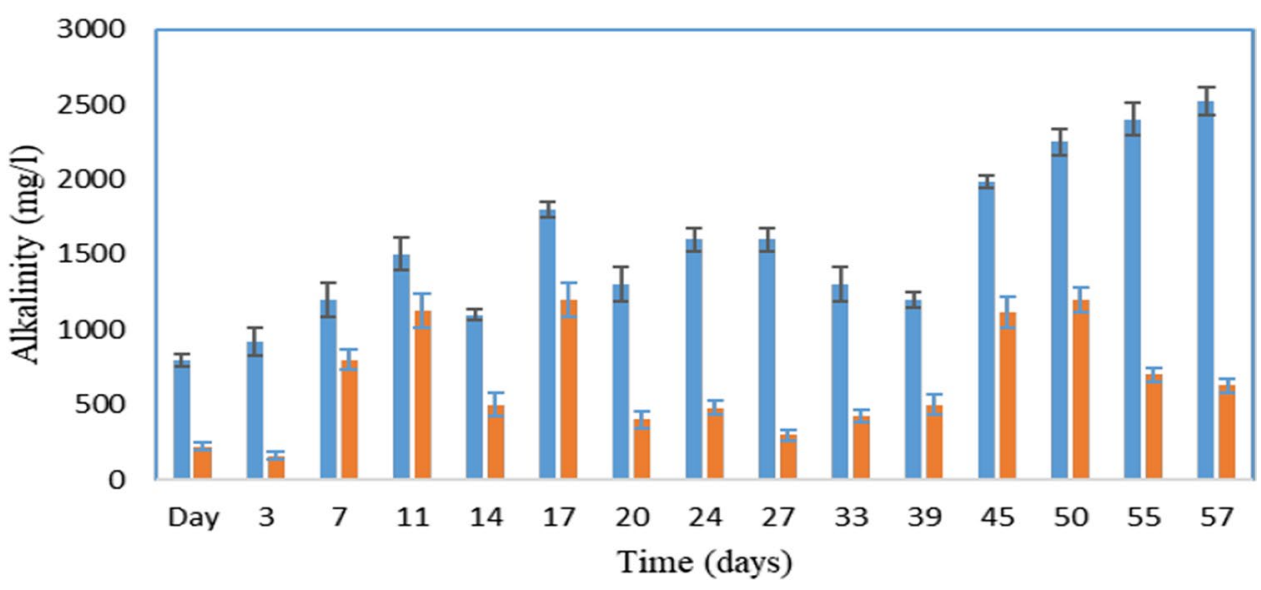


Table 6 Global comparison of slaughterhouse wastewater discharge standards and effluent from the present study

\begin{tabular}{|c|c|c|c|c|c|c|c|}
\hline Parameter & $\mathrm{BOD}_{5}(\mathrm{mg} / \mathrm{l})$ & COD (mg/l & TN (mg/l) & $\mathrm{TP}$ (mg/l) & TSS (mg/l) & $\mathrm{pH}$ & References \\
\hline World Bank & 30 & 125 & 10 & 2 & 50 & $6-9$ & [7] \\
\hline US EPA & $16-26$ & n.a & $4-8$ & n.a & $20-30$ & $6-9$ & [19] \\
\hline EU & 25 & 125 & $10-15$ & $1-2$ & $35-60$ & n.a & {$[67]$} \\
\hline China & $20-100$ & $100-300$ & $15-20$ & $0.1-1.0$ & $20-30$ & $6-9$ & {$[68]$} \\
\hline Canada & $5-30$ & n.a & 1.25 & 1.0 & $5-30$ & $6-9$ & [69] \\
\hline Colombia & 50 & 150 & 10 & n.a & 50 & $6-9$ & {$[70]$} \\
\hline Australia & $5-20$ & 40 & $10-20$ & 2 & $5-20$ & $6-9$ & {$[71]$} \\
\hline India & $30-100$ & 250 & $10-50$ & 5 & 100 & $5.5-9.0$ & {$[3,6]$} \\
\hline $\begin{array}{l}\text { Effluent from the SBR } \\
\text { reactor on the } 62 \text { nd day }\end{array}$ & 35 & 70 & 8.9 & n.a & 94 & 7.64 & [Present study] \\
\hline
\end{tabular}

recycling rate, and too much or too little may affect the performance of the reactor. In the present investigation, SVI was found to be $125 \mathrm{ml} / \mathrm{g}$ at the closing time of the reactor. It depicts flocculent settling, in which the sludge settles slowly and traps more particle matter before settling into a uniform blanket. For good biomass settling, SVI should be less than $100 \mathrm{ml} / \mathrm{g}$ [58].

The reactor contains a mixed culture of microbes; therefore oxidation of ammonia occurred due to nitrifying autotrophic bacteria. During carbon oxidation, a fraction of ammonia was assimilated by cell mass to synthesize new cells, and in the subsequent phase, dissimilatory ammonia removal happened to convert $\mathrm{NH}_{4}{ }^{+}-\mathrm{N}$ into $\mathrm{NO}_{2}-\mathrm{N}$ and $\mathrm{NO}_{3}{ }^{-}-\mathrm{N}$ under aerobic conditions. Excess sludge was used to maintain a microbial concentration inside the reactor. In this study, the sludge retention time (SRT) was manually controlled by withdrawing a volume of mixed liquor from the reactor every 7-8 days, resulting in 60 percent nitrification at the reactor's termination time. SRT should be longer than ten days to remove nitrogen efficiently $[9,11,58]$.

Table 6 shows current legislation and discharge limitations for organics and nutrients in SWW for proper environmental release in various jurisdictions across the globe, including the World Bank Group [7], the US EPA [19], the Council of the European Communities [67], the People's Republic of China Ministry of Environmental Protection [68], the Environment Canada [69], the Colombian Ministry of Environment and Sustainable Development Colombia [70], the Australian and New Zealand Environment and Conservation Council [71], and the Indian Central Pollution Control Board [3, 6]. The BOD, COD, TN, TSS, and $\mathrm{pH}$ of the effluent from the SBR reactor on the $62^{\text {nd }}$ day at the reactor's termination time are found to be within the allowable limits set by the Central Pollution Control Board (CPCB) of India.

\section{Conclusions}

According to the findings of this study, at the time of the reactor's decommissioning, the BOD and COD removal efficiency at an organic loading rate of $3.06 \mathrm{~kg} / \mathrm{m}^{3} / \mathrm{d}$ was 98 percent and 97 percent, respectively. The effluent $\mathrm{pH}$ and alkalinity were within acceptable limits, and the reactor's nitrification efficiency was around $60 \%$. The findings suggested that cylindrical SBR would be a preferable solution for slaughterhouse wastewater treatment. It has successfully extracted organic and nutrient components from wastewater without the use of chemicals or the addition of additional expenditures. Furthermore, because the microorganisms have become accustomed to the wastewater, the hydraulic retention period of a $24-\mathrm{h}$ cycle can be shortened by up to $12 \mathrm{~h}$. However, the results of laboratory experiments may not realistically reflect the performance at polluted sites. As a result, more large-scale field studies are needed to determine the performance of cylindrical SBR on a commercial scale. Its application would assist the industry since it consumes less space and power.

\section{Declarations}

Conflict of interest The authors declare that they have no known competing financial interests or personal relationships that could have appeared to influence the work reported in this paper.

\section{References}

1. Gerbens-Leenes PW, Mekonnen MM, Hoekstra AY (2013) The water footprint of poultry, pork and beef: A comparative study in different countries and production systems. Water Resour Ind 1:25-36. https://doi.org/10.1016/j.wri.2013.03.001 
2. Mekonnen MM, Hoekstra AY (2012) A global assessment of the water footprint of farm animal products. Ecosystems 15(3):401415. https://doi.org/10.1007/s10021-011-9517-8

3. Bustillo-Lecompte C, Mehrvar M (2017) Slaughterhouse wastewater: treatment, management and resource recovery. Phys-Chem Wastewater Treat Resour Recov, 153-174.

4. Valta K, Kosanovic T, Malamis D, Moustakas K, Loizidou M (2015) Overview of water usage and wastewater management in the food and beverage industry. Desalin Water Treat 53(12):33353347. https://doi.org/10.1080/19443994.2014.934100

5. Food and Agriculture Organization of the United Nations (2021) Meat Market Review. http://www.fao.org/3/cb3700en/cb3700en. pdf, Accessed 16 October 2021.

6. Central Pollution Control Board of India (2017) Revised comprehensive industry document on slaughterhouses. http:cpcb.nic. in/openpdffile.php?id=TGF0ZXN0RmlsZS8xNzVfMTUxMTI2 NDE0MV9tZWRpYXBob3RvODkzOS5wZGY=. Accessed 16 October 2021.

7. World Bank Group (2007) Environmental, Health and Safety Guidelines for Meat Processing. https://www.ifc.org/wps/wcm/ connect/e9ae040048865967b912fb6a6515bb18/Final\%2B-\% 2BMeat\%2BProcessing.pdf?MOD=AJPERES. Accessed 16 October 2021.

8. Central Pollution Control Board of India (2016) Slaughterhouse, meat and sea food industry. http://cpcb.nic.in/displaypdf.php?id= SW5kdXN0cnktU3B1Y2lmaWMtU3RhbmRhcmRzL0VmZmx1Z W50LzQ0Mi0xLnBkZg==. Accessed 16 October 2021.

9. Metcalf Eddy, Abu-Orf M, Bowden G, Burton FL, Pfrang W, Stensel HD, AECOM (Firm). (2014). Wastewater engineering: treatment and resource recovery. McGraw Hill Education.

10. Bello YO, Oyedemi DTA (2009) The impact of abattoir activities and management in residential neighbourhoods: A case study of Ogbomoso Nigeria. J Soc Sci 19(2):121-127

11. Kundu P, Debsarkar A, Mukherjee S (2013) Treatment of slaughter house wastewater in a sequencing batch reactor: performance evaluation and biodegradation kinetics. BioMed Res Int 2013:1-11

12. Aniebo AO, Wekhe SN, Okoli IC (2009) Abattoir blood waste generation in rivers state and its environmental implications in the Niger Delta. Toxicol Environ Chem 91(4):619-625

13. Bustillo-Lecompte CF, Mehrvar M (2015) Slaughterhouse wastewater characteristics, treatment, and management in the meat processing industry: A review on trends and advances. J Environ Manage 161:287-302. https://doi.org/10.1016/J.JENVMAN.2015. 07.008

14. Nandy T, Kaul SN (2001) Anaerobic pre-treatment of herbalbased pharmaceutical wastewater using fixed-film reactor with recourse to energy recovery. Water Res 35(2):351-362

15. Demirel B, Yenigun O, Onay TT (2005) Anaerobic treatment of dairy wastewaters: a review. Process Biochem 40(8):2583-2595. https://doi.org/10.1016/J.PROCBIO.2004.12.015

16. Choi YS, Hong SW, Kim SJ, Chung IH (2002) Development of a biological process for livestock wastewater treatment using a technique for predominant outgrowth of Bacillus species. Water Sci Technol 45(12):71-78

17. Fongsatitkul P, Elefsiniotis P, Yamasmit A, Yamasmit N (2004) Use of sequencing batch reactors and Fenton's reagent to treat a wastewater from a textile industry. Biochem Eng J 21(3):213-220

18. Schneider E, Cerqueira ACFP, Dezotti M (2011) MBBR evaluation for oil refinery wastewater treatment, with post-ozonation and BAC, for wastewater reuse. Water Sci Technol 63(1):143-148

19. United States Environmental Protection Agency (US EPA) (2004). Effluent limitations guidelines and new source performance standards for the meat and poultry products point source category [Internet] [Updated: 2004-10-08]. Available from: https://feder alregister.gov/a/04-12017. Accessed 16 October 2021
20. Torkian A, Eqbali A, Hashemian SJ (2003) The effect of organic loading rate on the performance of UASB reactor treating slaughterhouse effluent. Resour Conserv Recycl 40(1):1-11

21. Belsky AJ, Matzke A, Uselman S (1999) Survey of livestock influences on stream and riparian ecosystems in the western United States. J Soil Water Conserv 54(1):419-431

22. Bayar S, Yildiz Y, Yilmaz A, Koparal AS (2014) The effect of initial $\mathrm{pH}$ on treatment of poultry slaughterhouse wastewater by electrocoagulation method. Desalin Water Treat 52(16-18):3047-3053

23. Kundu P, Debsarkar A, Mukherjee S (2014) Kinetic modeling for simultaneous organic carbon oxidation, nitrification, and denitrification of abattoir wastewater in sequencing batch reactor. Bioremediat J 18(4):267-286

24. Torretta V, Martinez de Giraudo SL, Vazquez Minguela J, Sineriz F, Raboni M, Copelli S, Ragazzi M (2014) Treatment of effluents from slaughterhouses using anaerobic filters. Environ Technol 35(3):322-332

25. McCabe BK, Hamawand I, Harris P, Baillie C, Yusaf T (2014) A case study for biogas generation from covered anaerobic ponds treating abattoir wastewater: Investigation of pond performance and potential biogas production. Appl Energy 114:798-808

26. Jensen PD, Yap SD, Boyle-Gotla A, Janoschka J, Carney C, Pidou M, Batstone DJ (2015) Anaerobic membrane bioreactors enable high rate treatment of slaughterhouse wastewater. Biochem Eng J 97:132-141

27. Ozyonar F, Karagozoglu B (2014) Investigation of technical and economic analysis of electrocoagulation process for the treatment of great and small cattle slaughterhouse wastewater. Desalin Water Treat 52(1-3):74-87

28. Pan M, Henry LG, Liu R, Huang X, Zhan X (2014) Nitrogen removal from slaughterhouse wastewater through partial nitrification followed by denitrification in intermittently aerated sequencing batch reactors at $11 \mathrm{C}$. Environ Technol 35(4):470-477

29. Stets MI, Etto RM, Galvão CW, Ayub RA, Cruz LM, Steffens MBR, Barana AC (2014) Microbial community and performance of slaughterhouse wastewater treatment filters. Genet Mol Res 13(2):4444-4455

30. Yoon YM, Kim SH, Oh SY, Kim CH (2014) Potential of anaerobic digestion for material recovery and energy production in waste biomass from a poultry slaughterhouse. Waste Manage 34(1):204-209

31. Almandoz MC, Pagliero CL, Ochoa NA, Marchese J (2015) Composite ceramic membranes from natural aluminosilicates for microfiltration applications. Ceram Int 41(4):5621-5633

32. Odong R, Kansiime F, Omara J, Kyambadde J (2015) Tertiary treatment of abattoir wastewater in a horizontal subsurface flowconstructed wetland under tropical conditions. Int J Environ Waste Manage 15(3):257-270

33. Pan M, Hu Z, Liu R, Zhan X (2015) Effects of loading rate and aeration on nitrogen removal and $\mathrm{N} 2 \mathrm{O}$ emissions in intermittently aerated sequencing batch reactors treating slaughterhouse wastewater at $11 \mathrm{C}$. Bioprocess Biosyst Eng 38(4):681-689

34. Paramo-Vargas J, Camargo AME, Gutierrez-Granados S, Godinez LA, Peralta-Hernandez JM (2015) Applying electro-Fenton process as an alternative to a slaughterhouse effluent treatment. J Electroanal Chem 754:80-86

35. Wosiack PA, Lopes DD, Damianovic MHRZ, Foresti E, Granato D, Barana AC (2015) Removal of COD and nitrogen from animal food plant wastewater in an intermittently-aerated structured-bed reactor. J Environ Manage 154:145-150

36. Mees JBR, Gomes SD, Hasan SDM, Gomes BM, Vilas Boas MA (2014) Nitrogen removal in a SBR operated with and without predenitrification: effect of the carbon: nitrogen ratio and the cycle time. Environ Technol 35(1):115-123 
37. Abdurahman NH, Rosli YM, Azhari NH, Bari HA (2015) The potential of ultrasonic membrane anaerobic systems in treating slaughterhouse wastewater. J Water Reuse Desalin 5(3):293-300

38. Bustillo-Lecompte CF, Ghafoori S, Mehrvar M (2016) Photochemical degradation of an actual slaughterhouse wastewater by continuous UV/H2O2 photoreactor with recycle. J Environ Chem Eng 4(1):719-732

39. Keskes S, Hmaied F, Gannoun H, Bouallagui H, Godon JJ, Hamdi $M$ (2012) Performance of a submerged membrane bioreactor for the aerobic treatment of abattoir wastewater. Biores Technol 103(1):28-34

40. Shao Y, Shi Y, Mohammed A, Liu Y (2017) Wastewater ammonia removal using an integrated fixed-film activated sludge-sequencing batch biofilm reactor (IFAS-SBR): Comparison of suspended flocs and attached biofilm. Int Biodeterior Biodegradation 116:38-47

41. Vijayan G, Saravanane R, Sundararajan T (2016) Wastewater Quality Index-A Tool for Categorization of the Wastewater and Its Influence on the Performance of Sequencing Batch Reactor. Int J Environ Eng Manage 7(1):69-88

42. Mahvi AH (2008) Sequencing batch reactor: a promising technology in wastewater treatment, 79-90.

43. Prasanna K, Annadurai R, Godson MD, Murali A, Ashok I, Krishnan MV (2021) Treatment of septic tank effluent using sequencing batch reactor along with the incorporation of rice husk and Bael pericarp as a natural adsorbent in reducing BOD and COD. IOP Conf Ser: Mater Sci Eng 1101(1):012021

44. Huang W, Zhou J, He X, He L, Lin Z, Shi S, Zhou J (2021) Simultaneous nitrogen and phosphorus removal from simulated digested piggery wastewater in a single-stage biofilm process coupling anammox and intracellular carbon metabolism. Biores Technol 333:125152

45. Li D, Zhang S, Li S, Zeng H, Zhang J (2019) Aerobic granular sludge operation and nutrients removal mechanism in a novel configuration reactor combined sequencing batch reactor and continuousflow reactor. Biores Technol 292:122024

46. Jagaba AH, Kutty SRM, Lawal IM, Abubakar S, Hassan I, Zubairu I, Noor A (2021) Sequencing batch reactor technology for landfill leachate treatment: A state-of-the-art review. J Environ Manage 282:111946

47. Aziz SQ, Aziz HA, Yusoff MS, Bashir MJ (2011) Landfill leachate treatment using powdered activated carbon augmented sequencing batch reactor (SBR) process: Optimization by response surface methodology. J Hazard Mater 189(1-2):404-413

48. Mpofu AB, Oyekola OO, Welz PJ (2021) Anaerobic treatment of tannery wastewater in the context of a circular bioeconomy for developing countries. J Clean Product 296:126490

49. Durai G, Rajamohan N, Karthikeyan C, Rajasimman M (2010) Kinetics studies on biological treatment of tannery wastewater using mixed culture. Int J Chem Mol Nucl Mater Metall Eng 4(1):118-122

50. Zheng Z, Li J, Wang C (2021) Rapid cultivation of the aerobic granules for simultaneous phenol degradation and ammonium oxidation in a sequencing batch reactor. Biores Technol 325:124414

51. Bendjama Z, Amrane A, Kaouah F, Hamane D, Ikkene R (2012) Biodegradation of P-cresol by mixed culture in batch reactor-effect of the three nitrogen sources used. Procedia engineering 33:458-464

52. Hjalmarsson L (2021) Hydrolysis of waste activated sludge from pulp and paper mills: effect on dewatering properties and biogas potential by utilizing existing side streams.

53. Jafarinejad S (2017) Recent developments in the application of sequencing batch reactor (SBR) technology for the petroleum industry wastewater treatment. Chem Int 3(3):241

54. Thompson G, Swain J, Kay M, Forster CF (2001) The treatment of pulp and paper mill effluent: a review. Biores Technol 77(3):275-286

55. de Sousa Rollemberg SL, Barros ARM, de Lima JPM, Santos AF, Firmino PIM, dos Santos AB (2019) Influence of sequencing batch reactor configuration on aerobic granules growth: engineering and microbiological aspects. J Clean Product 238:117906
56. Sekine M, Akizuki S, Kishi M, Toda T (2018) Stable nitrification under sulfide supply in a sequencing batch reactor with a long fill period. J Water Process Eng 25:190-194

57. Ghodeif K (2013) Baseline Assessment Study for Wastewater Treatment Plant for Al Gozayyera Village, West Kantara City, Ismailia Governorate, Egypt. Network of Demonstration Activities for Sustainable Integrated Wastewater Treatment and Reuse in the Mediterranean: Cairo, Egypt

58. Kariuki TA (2014) University of Nairobi construction engineering sequencing batch reactor in treatment of master of science in civil engineering A Thesis Submitted in Partial Fulfillment for the Degree of Master of Science in Civil Engineering in the Department of Declaration / Approval, (February).

59. American Public Health Association (APHA) (2003) Standard method for the examination of water and wastewaters (21st edn), Washington DC, USA.

60. Li JP, Healy MG, Zhan XM, Rodgers M (2008) Nutrient removal from slaughterhouse wastewater in an intermittently aerated sequencing batch reactor. Biores Technol 99(16):7644-7650

61. Musa MA, Idrus S (2021) Physical and Biological Treatment Technologies of Slaughterhouse Wastewater: A Review. Sustainability 13(9):4656

62. Baker BR, Mohamed R, Al-Gheethi A, Aziz HA (2021) Advanced technologies for poultry slaughterhouse wastewater treatment: A systematic review. J Dispersion Sci Technol 42(6):880-899

63. Baker B (2016) Explore the pollution load of slaughterhouse wastewater and their treatment potential using biofilm reactor. Int J Sci Eng Res 7:1757-1761

64. Gallert C, Winter J (2005) Bacterial metabolism in wastewater treatment systems. Environmental Biotechnology. Concepts and Applications.

65. Casellas M, Dagot C, Baudu M (2006) Set up and assessment of a control strategy in a SBR in order to enhance nitrogen and phosphorus removal. Process Biochem 41(9):1994-2001

66. de Sousa Rollemberg SL, Barros ARM, Firmino PIM, Dos Santos $A B$ (2018) Aerobic granular sludge: cultivation parameters and removal mechanisms. Biores Technol 270:678-688

67. Council of the European Communities (CEC) (1991) Urban Wastewater Treatment Directive 91/271/EEC. Official Journal of the European Communities. 135(30.5):40-52.

68. Chinese Ministry of Environmental Protection (1991) Discharge standard of water pollutants for meat packing industry GB 13457-92. Available from: http://english.mep.gov.cn/standards_reports/stand ards/water_environment/Discharge_standard/200710/t20071024_ 111799.htm. Accessed 2021-08-24

69. Environment Canada (2012) Wastewater Systems Effluent Regulations. Fisheries Act. SOR/2012-139 [Updated: 2016-06-17]. Available from: http://laws-lois.justice.gc.ca/eng/regulations/sor-2012139/FullText.html. Accessed: 2021-08-24

70. Colombian Ministry of Environment and Sustainable Development (2015) Resolution 631 of 2015 Whereby the parameters and maximum permissible exposure limits in specific discharges to surface water and public sewer systems and other provisions are established. Available from: https://www.minambiente.gov.co/images/ normativa/app/resoluciones/d1-res_631_marz_2015.pdf. Accessed: 2021-08-24

71. Australian and New Zealand Environment and Conservation Council (2000) Australian and New zealand guidelines for fresh and marine water quality. Natl Water Qual Manage Strateg 1(1-7):4 